\title{
冬季西南日本太平洋側に発生する雲バンドと 地上気象要素分布の関係
}

\author{
仁 科 淳 司* \\ On the Relation between the Band Clouds on the Pacific \\ Ocean Side in Winter and the Distribution of the \\ Surface Meteorological Elements
}

Junji Nishina

\begin{abstract}
In his preceding paper (NISHINA 1984), the author discussed an orographic effect on the cloud distribution in the Central Japan under the winter monsoon situation. Such an orographic effect is considered to exist also in the Southwest Japan in winter. The purpose of this study is to examine the relation between the location of the band clouds on the Pacific Ocean side in the Southwest Japan and the distribution of surface meteorological elements, and to discuss an orographic effect on the distribution of these band clouds in this region.

In this study, the author used GMS sector visible pictures at 00 GMT on the all days in three winters (December, January and February) from December in 1978 to February in 1981. Of these all pictures, the pictures of the 42 days on which appeared at least four lines of band clouds of six as shown in Fig. 2 were analyzed. In my preceding paper, the result was obtained that the generation of local anticyclones and cyclones differs under different wind direction at $800-850 \mathrm{mb}$ altitude. According to this result, the 42 days were classified into four types (W, WNW, NW, NNW) by the wind direction at $850 \mathrm{mb}$ altitude in Shionom isaki. Meteorological elements at $850 \mathrm{mb}$ altitude and at the surface were analyzed in each type.

The results are summarized as follows:

1. The band clouds in the leeward of the Kii Mts., the Shikoku Mts., or the Kyushu Mts. all appear from the low pressure region in the leeward of these mountains. But the appearance rate of these band clouds differs under different upper ( $850 \mathrm{mb}$ level) wind direction, which can be explained by the relation between the upper wind direction and the direction of these mountains.

2. The band cloud from the Kii Strait appears along the line of discontinuity of wind extending from the low pressure region in the leeward of the Chugoku Mts. when northnorthwesterly upper wind blows. Under westerly wind, it does on the outburst of the wind from the Kanmon Strait through the Seto Inland Sea. But in the latter case, no band
\end{abstract}

* 東京大学理学部地理学教室 Department of Geography, University of Tokyo 
cloud appears when high pressure region expands strongly from the Shikoku Mts. to the Kii Mts.

3. The outburst of the wind from the Kanmon Strait plays basically an important role in the appearance of the band cloud from the Bungo Strait. Under westerly upper wind, a line of discontinuity of wind is made of this outburst and the wind from the anticyclone generating near Kumamoto in the windward of the Kyushu Mts.. A band cloud appears along this line. Under north-northwesterly upper wind, the cold air current from the anticyclone generating near Hita in the windward of the Kyushu Mts. is brought to the west of this outburst, where a band cloud appears.

\section{I. はじめに}

さきに，筆者は，冬季季節風下で中部日本周辺に見られる雲分布に対する地形効果について考察した (仁科 1984 ; 以下「前報」と呼ぶことにする)。その中で, 筆者は, $800 \sim 850 \mathrm{mb}$ の風向の違いによって, 地形性高気圧・低気圧の発生のしかたが異なり，それが雲分布を規定していることを指摘した。

ところで, すでに岡林 (1972), TsuChIYA and FujiTA (1967), TsuChIYA (1974), 黒坂 (1981, 1982) などが指摘しているように, 西南日本でも, 冬季, 太平洋側に雲バンドが発生する。しかし, これら の研究では, 雲バンドの位置とその風上側の地形との対応が指摘されたのみである。楅間 (1980) も, 雲 バンドの発生の原因として, 地上風の収束である可能性を指摘しているが, 実証するまでには至っていな い。この地域には, 紀伊山地, 四国山地, 九州山地などの, $1,000 \sim 1,500 \mathrm{~m}$ 以上の山地が連なり, これら によって大気の自由な運動が制約されるため, 中部日本と同様に, 雲バンドの 分布が, 前報で述べたよう な地形効果によって決められている可能性がある。にもかかわらず, この地形効果は指摘されていない。

本研究では, 西南日本を研究対象地域として, 冬季太平洋側に発生する雲バンドと, 地形性高気圧（高 圧部) ・低気圧 (低圧部) の分布の特徵とを関連つけて検討し, 地形効果について考察することを目的とす る。

\section{II. 瓷料と方法}

本研究では, Fig. 1 で示した地域内の各観測点における地上・高層データの解析と, GMS 画像による 西南日本太平洋側の雲バンドの解析とを対応させることにより, 地上気象要素分布の特徵と, 雲分布との 関連を考察する。

GMS の画像によると, 冬季, 西南日本太平洋側に発生する雲バンドは, その発生位置を基準にすると, Fig. 2 のように, $\mathrm{a} \sim \mathrm{f}$ の 6 列が存在する。ここで, $\mathrm{a}$ は紀伊半島沖から発生するもの, b は紀伊水道か ら発生するもの， c は四国東部の沖で, 剣山の風下に相当する位置から発生するもの, $\mathrm{d}$ は土佐湾から発 生するもの, e は豊後水道から発生するもの, f は九州山地沖に発生するものである。

本研究では，1978年12月から1981年 2 月までの 3 冬季 (12月，1月，2月）の毎日午前 9 時の部分円形可 視画像のうち, 上記の 6 列の雲バンド中, 少なくとも 4 列の発生が認められる日を, 解析対象日とした。 この条件を満たす日は合計42日である。この42日の解析対象日は, YosHINO and KAI (1974) の分類に 従うと, すべて西高東低型 ( I 型) に属する。また, 黒坂 (1982), KUROSAKA (1983) は, 太平洋側の雲 バンドは, 西高東低の気圧配置下で多く発生することを指摘している。したがって, この 42 日は, 冬季の 季節風が卓越する日であると見なすことができる。

さらに, 前報で, $800 \sim 850 \mathrm{mb}$ の風向の違いによって地形性高気圧, 低気圧の発生のしかたが異なること がわかったので, この 42 日の解析対象日を, $800 \sim 850 \mathrm{mb}$ の風向によって, いくつかの型に分類することを 試みた。太平洋側の雲バンドの主体が対流性の積雲系の雲であることは, すでに TSUCHIYA and FUJITA 


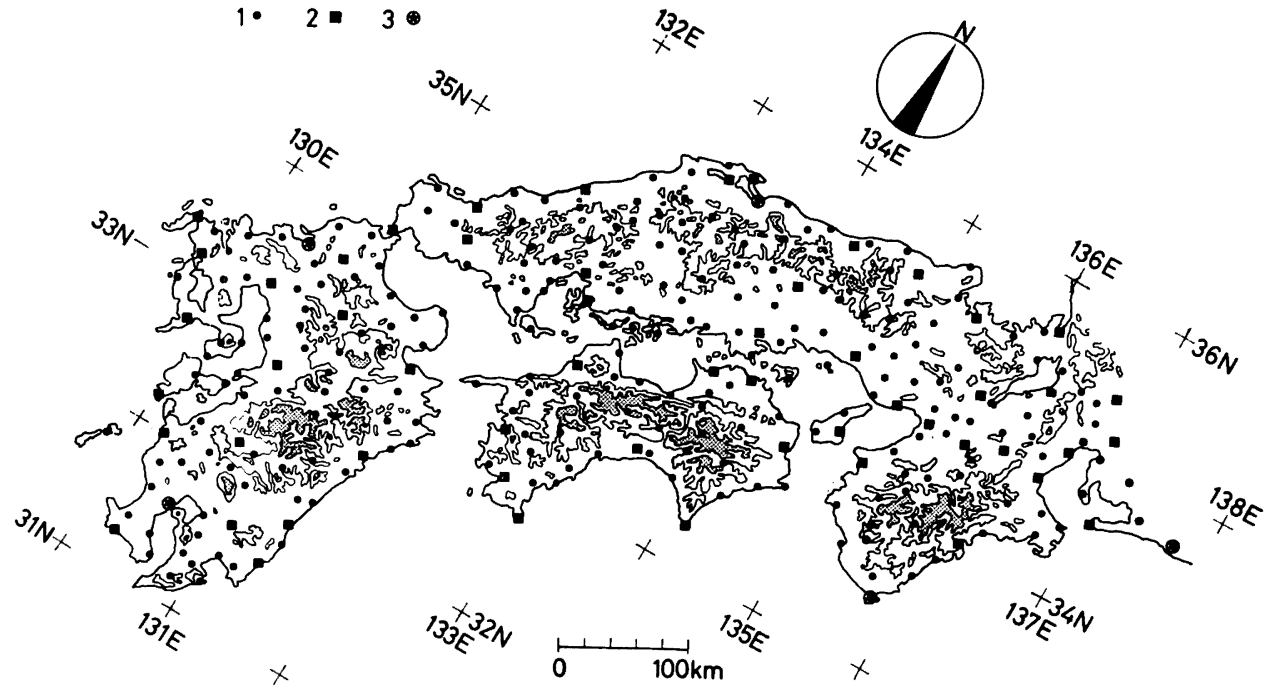

Fig. 1 Location of the observatories and stations

1: AMeDAS station (wind only), 2: weather observatory (wind, temperature, sea level pressure), 3: aerological observatory (surface wind, surface temperature, sea level pressure, $850 \mathrm{mb}$ isobaric surface wind, $850 \mathrm{mb}$ isobaric surface altitude). Contours are drawn at the height of $500 \mathrm{~m}$ and $1000 \mathrm{~m}$, respectively. The areas over $1000 \mathrm{~m}$ are shaded.

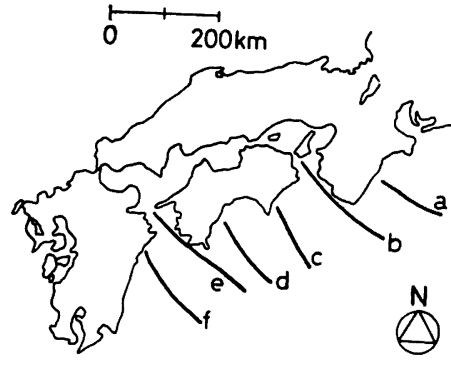

Fig. 2 Band clouds on the Pacific Ocean side in the Southwest Japan in winter

(1967)，TSUCHIYA（1974）で示されており，また KUROSAKA （1983）は，伊豆半島沖ならびに紀伊山地沖の雲バンドについて， レーダーエコーから積雲の上端の高さを $1 \sim 2 \mathrm{~km}$ としている。し たがって, $800 \mathrm{mb}$ 面の気象要素の值よりも, $850 \mathrm{mb}$ 面の方が, 積 雲の対流活動の上限を反映するものとして適当であり, 前報でも触 れたように, $900 \mathrm{mb}$ 面の值には地面摩擦の影響が現われていると 考えられるので, $850 \mathrm{mb}$ 面の風向を分類の基準にした。ところで, 地形効果は中部山岳の風下側に位置する浜松の風向の観測值に最も よく反映されることを，筆者は前報で指摘した。したがって，解析 対象地域の風下側に位置する観測点 (浜松・潮岬・鹿児島) のうち, 西南日本全体を最もよく代表すると思われる 潮岬における $850 \mathrm{mb}$ 面の風向によって，解析対象日を分類した。

潮岬における $850 \mathrm{mb}$ 面の風向により，Table 1 のように，W， WNW， NW， NNW の4つの型に分類し，各型ごとに代表的と思われる 1 日を選び，その日の雲分布 の模式図を Fig. 3 に示す。その上で，各型ごとに, $850 \mathrm{mb}$ 面の等圧面高度・風向・風速を解析し,つい で地上の風系・海面更正気圧・気温の解析を行なって, 雲バンドの発生と地上気象要素分布との対応につ いて, 解析を進める。

また, Table 1 に示した四つの型ごとに, Fig. 2 に示したa〜f の雲バンドの発生頻度をみると (Table 2 ), 雲バンド a , f の発生頻度の全体に対する割合 (発生率) は, NNW 型で低く（ 5 例中 1 例), W型 で高い（10例中それぞれ 8 例，10例)。雲バンドbの発生率は，W型で低く（10例中 5 例), $850 \mathrm{mb}$ 面の風 向の北成分が大きくなるにつれて高くなる。雲バンド $\mathrm{c} \cdot \mathrm{d}$ は, NNW 型で最も発生率が高く（5例中 5 
Table 1 The classification of the 42 days for analysis into four types Unit of wind direction : degree.

\begin{tabular}{|c|c|c|c|}
\hline type & $\begin{array}{l}\text { wind direction at } 850 \mathrm{mb} \\
\text { height in Shionomisaki }\end{array}$ & date & total \\
\hline W & $260-285$ & $\begin{array}{l}\text { '79.12.26, '80.1.7, '80.1.16, '80.1.21, '80.2.15, } \\
\text { '80.12.13, '81.1.3, '81.1.5, '81.1.12, '81.1.13 }\end{array}$ & 10 \\
\hline WNW & $285-310$ & $\begin{array}{l}\text { '79.1.22, '79.2.6, '79.2.16, '79.2.18, '79.2.28, } \\
\text { '80.1.11, '80.1.24, '80.1.31, '80.12.15, '80.12.21, } \\
\text { ' } 80.12 .29, \quad 80.12 .31, \quad 81.1 .6, \quad 81.2 .11, \quad 81.2 .21\end{array}$ & 15 \\
\hline NW & $310-335$ & $\begin{array}{l}\text { '78.12.6, '78.12.24, '79.1.16, '79.1.19, '80.1.18, } \\
\text { '80.2.6, '80.2.12, '81.1.4, '81.1.14, '81.1.22, } \\
\text { '81.2.4, '81.2.27 }\end{array}$ & 12 \\
\hline NNW & $335-360$ & '79.12.11, '79.12.24, '80.2.16, '81.1.17, '81.2.2 & 5 \\
\hline
\end{tabular}

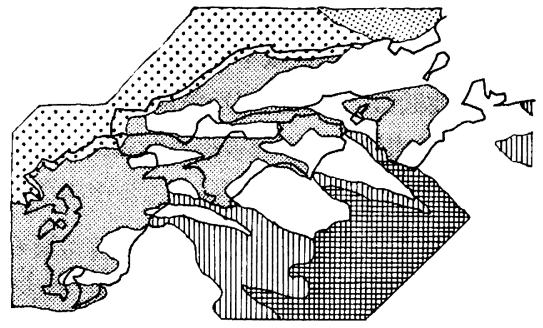

W type [ex: 21 JAN 80]

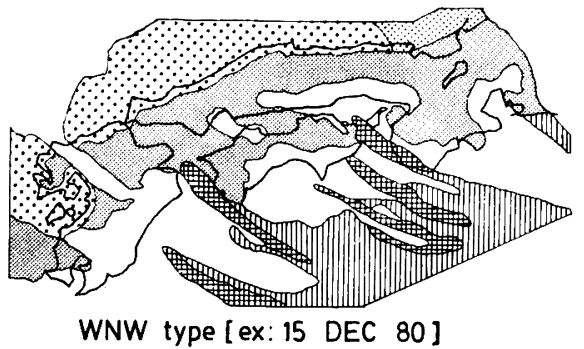

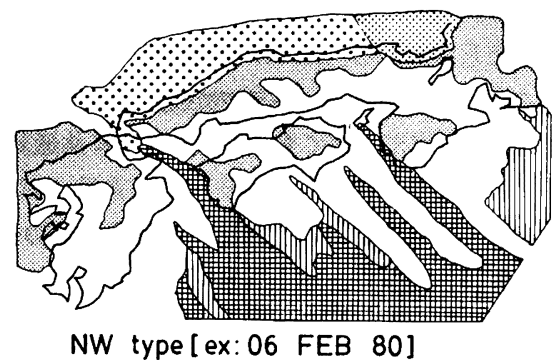

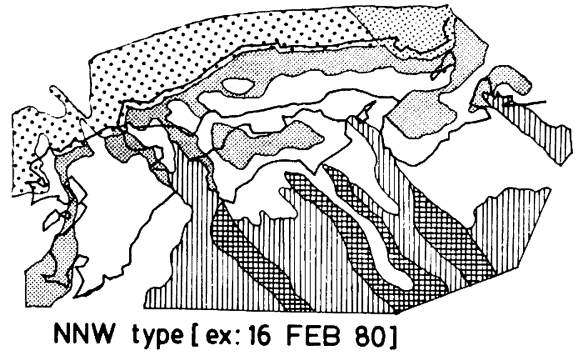

NNW type [ex: 16 FEB 80]

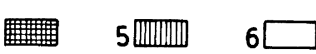

Fig. 3 Typical pattern of the cloud distribution in each type 1: convective band cloud (after Meteorological Satellite Center 1983; NiSHINA 1984), 2 : cloud streak (after OKABAYASHI 1972), 3 : other cloud or snowcover, $4:$ band cloud (brighter part), 5 : band cloud, 6 : cloudless region.

例), $850 \mathrm{mb}$ 面の風向の北成分が小さくなるにつれて, 発生率は低くなる。雲バンド $\mathrm{e}$ は, すべての解析対 象日に共通して発生する。本研究では, このような高層風向の違いによる発生率の違いについても考察す る。 
Table 2 The frequency of the appearance of each band cloud shown in Fig. 2

\begin{tabular}{|c|c|c|c|c|c|c|c|}
\hline \multirow{2}{*}{ type } & \multicolumn{6}{|c|}{ band cloud } & \multirow{2}{*}{ total } \\
\hline & $\mathrm{a}$ & $\mathrm{b}$ & c & $\mathrm{d}$ & e & $f$ & \\
\hline W & 8 & 5 & 7 & 9 & 10 & 10 & 10 \\
\hline WNW & 11 & 9 & 12 & 9 & 15 & 13 & 15 \\
\hline NW & 7 & 12 & 10 & 12 & 12 & 7 & 12 \\
\hline NNW & 1 & 5 & 5 & 5 & 5 & 1 & 5 \\
\hline
\end{tabular}

5 点の高層観測地点を使って，潮岬を必ず頂点の一つに含むような 4 個の三角形を考えた。そして, こ の各三角形の重心に相当する点と, 各辺の四等分点（ただし, 福岡一鹿児島と潮岬一浜松を結ぶ辺につい ては，距離が短いため，中点のみを対象にした）における等圧面高度の值を，内插によって求めた。この 值から, 等高度線を描いた。日本海上ならびに太平洋上では, 想定される風ベクトルに対して, 平行に近 くなるよう描いた。

Fig. 4 から, 850mb 面では, すべての型に共通して, 紀伊・四国・九州の各山地の風下に, トラフが存 在していることがわかる。NNW 型の場合は, 他の型よりも北にトラフが位置する。前報で, $800 \sim 850 \mathrm{mb}$ 面において中部山岳の風下にトラフが見られ，その時地上に局地低気圧（低圧部）が存在することから 推 定すると, 西南日本においても, すべての型に共通して, これらの山地の風下側に局地低気圧（低圧部）が 現われることが考えられる。

\section{2）地上風系図ならびに地上気圧・気温分布図の作成方法}

つぎに, 前報と同様に, 地上風系図, 地上気圧・気温分布図を作成して, 各型ごとに, 雲バンドの発生
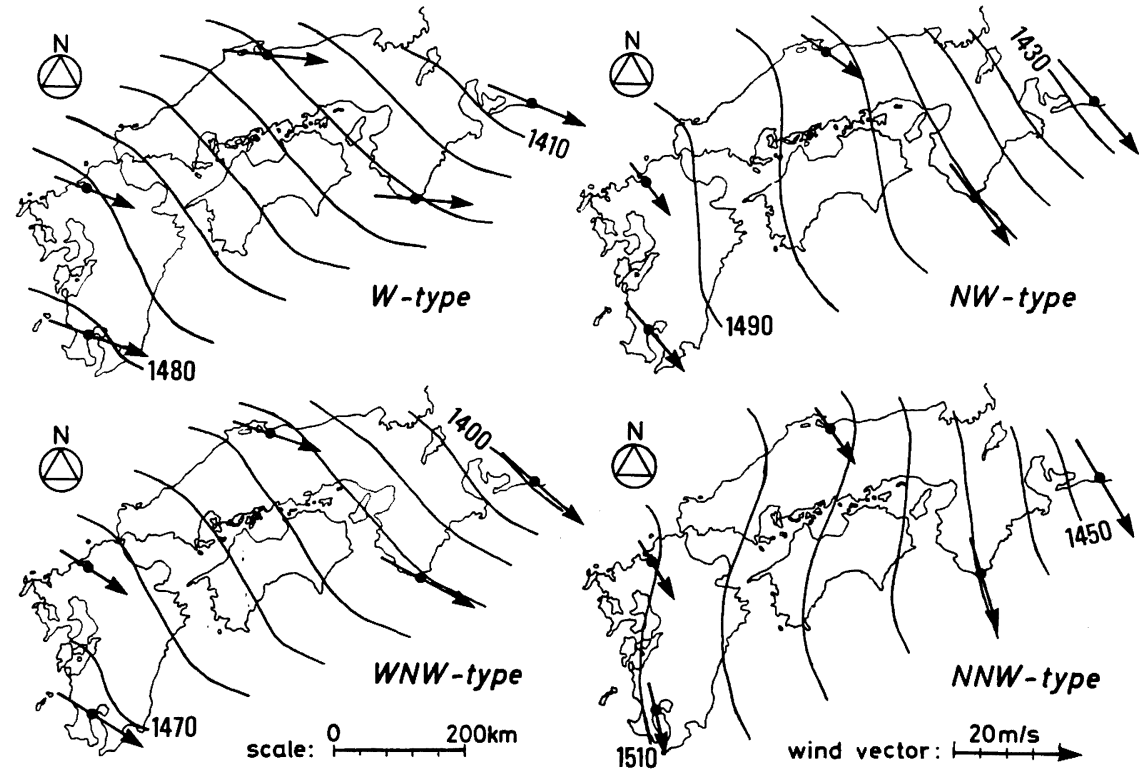

Fig. 4 Distribution of wind vector and altitude at $850 \mathrm{mb}$ surface Unit of altitude : gpm. 
位置と, 地上気象要素の分布の特徽との関連を検討する。

地上風系図は以下の方法で作成した。まず，各型ごとに，各観測点の風向を検討し，最も高い頻度を示 す風向（最多風向）を求めた。このとき, 静稳の場合は, 「最多風向から風速 $0 \mathrm{~m} / \mathrm{s}$ の風が吹く」場合と解 釈した。この最多風向から風の吹く日が，ある型に属する日の半数以上を占める場合は，その風向を卓越 風向と定めた。それ以外の場合は, 最多風向と， 2 番目に頻度の高い風向を求めた。この 2 つの風向のな す角度が22.5度の範囲内の場合は, 最多風向を卓越風向と定め, 45 度の範囲内の場合は, 2 つの風向の中 間を卓越風向とした。最多風向が 2 つある場合も，同様の方法で卓越風向を決定した。また，2番目に頻 度の高い風向が 2 つあり, かつ, この 2 つの風向と最多風向が連続して 45 度の笨囲内にある時は, 最多風 向を卓越風向とした。以上のいずれの方法でも卓越風向が定まらない場合は，その観測点を 不安定風域 (unstable wind region) と認定した。

つぎに, こうして定められた卓越風向に対して， \pm 22.5 度の範囲内から吹く風だけについて，その風速 の卓越風向成分を求めた。この值から 各型ごとに平均値を算出し，その地点におけるその型の平均風速と した。

こうして求めた卓越風向と平均風速を用いて, 地上風采図を描いた。平均風速については, $4 \mathrm{~m} / \mathrm{s}$ と 1 $\mathrm{m} / \mathrm{s}$ の等値線を考え, 平均風速 $4 \mathrm{~m} / \mathrm{s}$ 以上の地域を強風域 (strong wind region), $1 \mathrm{~m} / \mathrm{s}$ 末満の地域を静 穏域（calm region）として図示した。海上の流線は風向・風速の内挿により描いた。

地上気圧と地上気温については，各観測点の値を 各型ごとに平均し，この值を用いて分布図を作成し た。地上気圧分布図については，上記の方法で作成した地上風系図を参考にして，等圧線を描いた。

以上のようにして作成した地上風系図，地上気圧・気温分布図を用いて，まずW型と NNW 型，つぎに この 2 つの中間である WNW 型と NW 型の順に, 地上気象要素分布の特徴を検討する。

\section{3）W型における地上気象要素分布の特徵}

Fig. 5 は，W型における地上風系図(a)および地上平均気圧・気温分布図(b)である。雲バンドの発生位置 と地上気象要素分布図を対応させると，以下のことがわかる。

紀伊・四国・九州の各山地の風下から発生する雲バンド $\mathrm{a} \cdot \mathrm{c} \cdot \mathrm{d} \cdot \mathrm{f}$ の位置と，地上平均気圧分布図 における低圧部の位置が一致している。すなわち, 尾鹪・高知・延岡が低圧部に相当し, 室戸岬の東側の 四国山地風下にも小さな低圧部が現われる。

地上風系図から，雲バンド $\mathrm{b} の$ 発生する位置には，強い風の吹き出しが認められる。この吹き出しの風 上側の高松付近には低気圧が認められる。紀伊水道の両側の気温を見ると，東側の方が高く，西側，すな わち風上側の方が低いことがわかる。

雲バンド $\mathrm{e}$ が発生する豊後水道では, 地上風系図から，大分付近で，関門海峡から吹き出した風と，九 州山地の風上側からの風が収束していることがわかる。地上気圧分布図から，この収束の位置に，小さな 低圧部が対応していることがわかる。九州山地の風上側には，熊本付近を中心とした局地高気圧が現われ る。

\section{4） NNW 型における地上気象要素分布の特徴}

Fig. 6 は, NNW 型における地上風系図(a)および地上平均気圧・気温分布図(b)である。雲バンドの位置 と地上気象要素との対応を見ると, 雲バンド $a \cdot c \cdot d \cdot f$ は, 地上平均気圧分布図における低圧部から

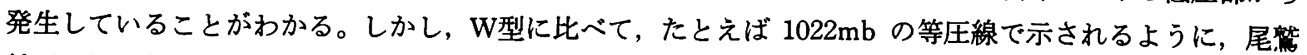
付近の低圧部は明瞭ではない。同様に九州山地の風下の低圧部も，W型に比べてはっきりしない。九州山 地の風上側に発生する高気圧の中心は，W型では熊本付近にあるのに対し, NNW 型では日田付近にあ る。

雲バンド $\mathrm{b}$ に対応する 地上気象要素分布の特徴は, W型の場合とは大きく異なる。すなわち, NNW 型 では, 紀伊水道で明瞭な風の収束が見られる。中国山地の風下側には低圧部が認められる。紀伊水道の両 

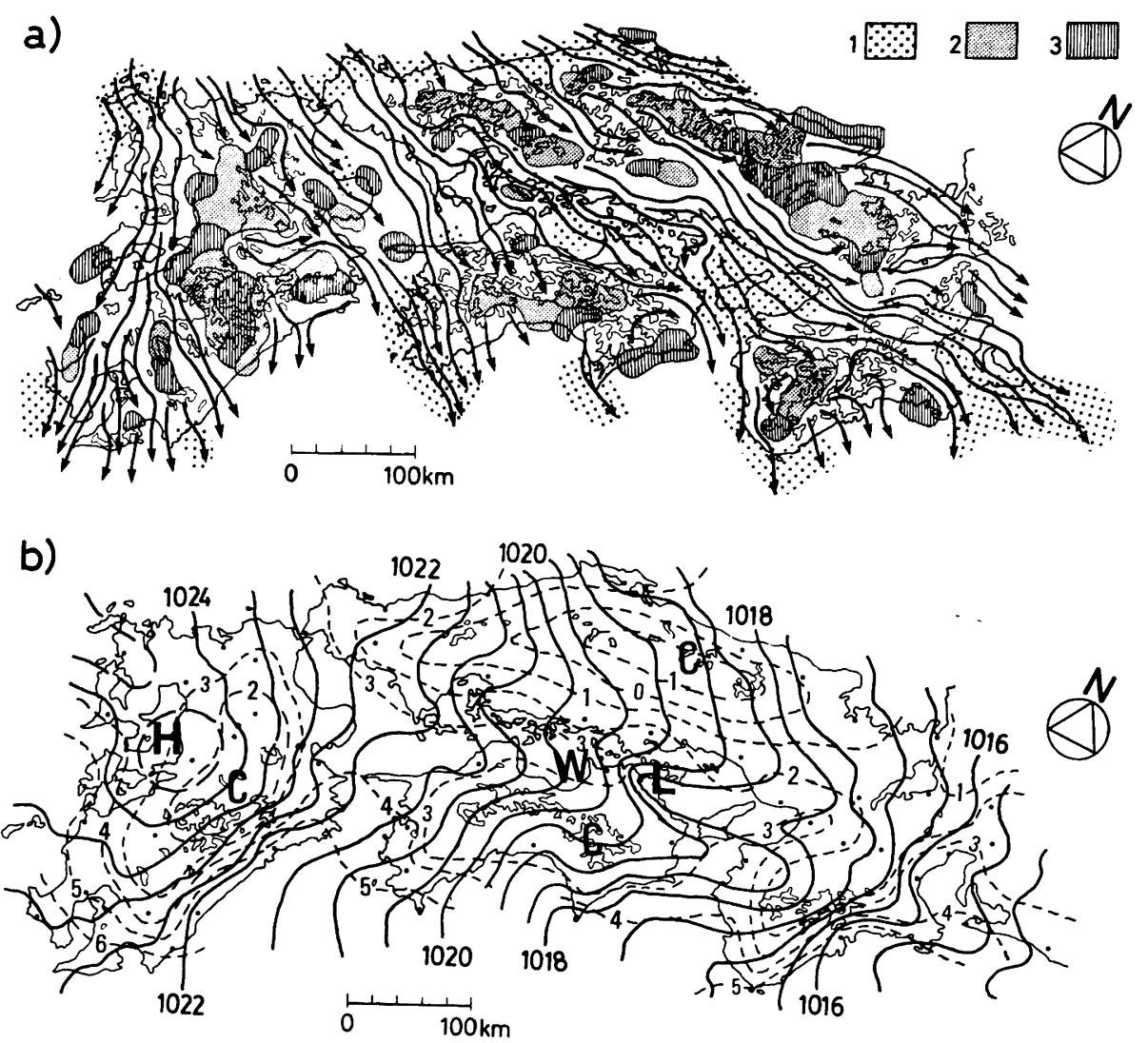

Fig. 5 Composite map of surface wind system (a), and sea level pressure (solid line, unit: $\mathrm{mb}$.) and surface temperature (dashed line, unit: ${ }^{\circ} \mathrm{C}$.) (b) in $W$ type 1 : strong wind region, 2 : calm region, 3 : unstable wind region. See text for definitions.

側の地上気温を比べると，西側で高く，東側で低いことがわかる。ただし，大阪における気温の值は， 七 ートアイランドの形成を考え，若干割り引いて考えている。

雲バンド $\mathrm{e}$ に対応する地上気象要素分布の特徽を検討すると, 関門海峡からの風の吹き出しが認められ る。地上風采図における風の流線は, 豊後水道の九州側を通っている。豊後水道の四国側は弱い低圧部に なっている。また, 九州内陸部の地上気温と, 豊後水道付近の地上気温との差は, W型に比べて大きい。 九州内陸部に高気圧が存在し, 豊後水道付近が弱い低圧部になっていることから, 豊後水道付近には, 九 州内陸部の高気圧からの寒冷な気流が供給されていることが示唆される。

\section{（5） WNW 型・NW 型における地上気象要素分布の特徵}

$\mathrm{WNW}$ 型・NW 型においては，図は示さないが，雲バンド a ・ c ・ d ・ f の発生位置に対応するの は, 紀伊・四国・九州の各山地の風下に現われる低圧部であり,この特徽は WNW 型・NW 型の双方に 共通である。紀伊山地や 九州山地の風下に現われる低圧部の周辺の等圧線の走向は, WNW 型の場合は $\mathrm{W}$ 型に近く, NW 型の場合は NNW 型に近い。九州山地の風上側に認められる高気圧の発生のしかたは, 

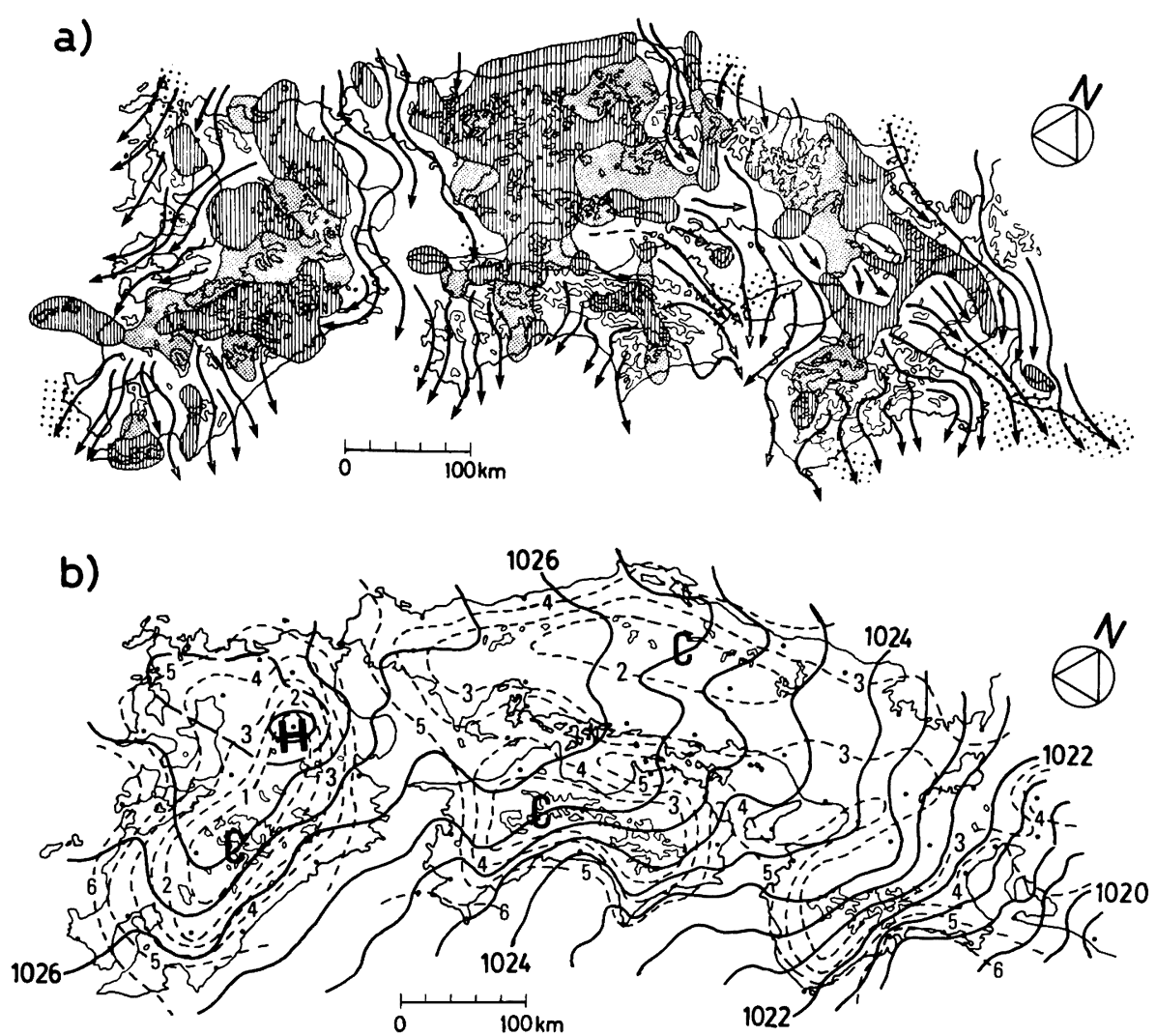

Fig. 6 Same as in Fig. 5, but in NNW type

WNW 型の場合はW型に近く, NW 型の場合は NNW 型に近い。

紀伊水道付近の地上気象要素分布の特徽を検討すると, WNW 型における分布の特徽はW型に近い。地 上風系図では，広島付近から紀伊水道にかけて，顕著な風の吹き出しが認められ，雲バンド $\mathrm{b} の$ 発生する 位置と, この吹き出しの位置が対応している。W型でも見られるように, 高圧部が四国山地から 紀伊山地 側に張り出しているが, その張り出し方はW型に比べて弱い。W型と異なり, 高松付近に低圧部は存在し ない。また, NW 型の場合, 中国山地の風下の低圧部は NNW ほど明瞭ではないが, 地上風采図から, 松 江の南の中国山地の風下側に風の収束域が見られ，ここからほぼ南東に，風の不連続線が紀伊水道まで延 びていることがわかる。NW 型では, この不連続線の位置と，雲バンド $\mathrm{b}$ の発生する位置が対応している。

雲バンド e に対応する地上気象要素分布の特徵を検討すると, WNW 型・NW 型ともに, 関門海峡か らの風の吹き出しが認められる。WNW 型の豊後水道付近における地上風系はW型に類似し, 関門海峡か らの風と, 九州山地からの風が, 大分付近で収束する。九州山地の 風上側の局地高気圧は, 中心が熊本付 近にあるが, W型と異なり，大分付近の低圧部は不明瞭である。これに対して，NW 型の豊後水道付近に おける地上風系をみると, NNW 型と同様に, 関門海陕からの風の吹き出しが認められ，風の流線は, 豊後水道の四国側を通っている。九州山地の風上側の局地高気圧の中心は, 日田付近に位置する。また, NNW 型ほどではないが, NW 型でも, 九州内陸部と豊後水道付近の気温差は大きい。したがって, 
NNW 型と同様に, 九州山地の風上側の高気圧から，豊後水道付近に 冷気流が供給されていることが示唆 される。

\section{IV. 考 察}

以上の解析から, Fig. 2 に示した雲バンドごとに, 地上気象要素分布の特徴との対応を考察する。あわ せて, Table 2 で示したような, 高層風向別の雲バンドの発生率の違いについても, 考察の対象とする。

1. 雲バンド $\mathrm{a} \cdot \mathrm{c} \cdot \mathrm{d} \cdot \mathrm{f}$ は, 紀伊・四国・九州の各山地の風下に認められた低圧部から発生するこ とがわかる。ところで, 山地の風上側に高圧部が，風下側に低圧部が出現することは，すでに QUENEY

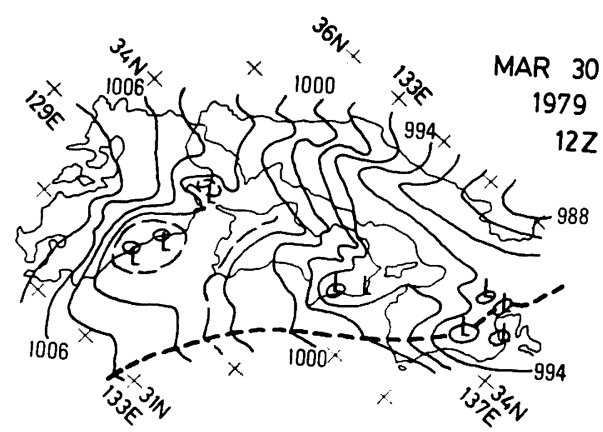

Fig. 7 Local weather map at $12 Z$ on March 30 in 1979 (MIYAMOTO 1981)

Unit : mb., thick broken line : front.

(1948) などによって指摘されている。一方, 宮本 (1981) は, Fig. 7 に示すように, 寒冷前線通過直後の強い吹き 出しの時に, 九州・四国の各山地の 風下に小低気圧が 発生することを指摘した。また, CHOU and ATLAS (1982) や ATLAS et al. (1983) は, アメリカ合衆国 ニュージャージー州沖の雲バンドが, 海岸付近に発生す る小低気圧から風下側に延びる風の不連続線上に発生す ることを指摘している。したがって, 雲バンド a ・ c ・ $\mathrm{d} \cdot \mathrm{f}$ に関しても, 山地の風下に発生する低圧部, なら びにここから延びる風の不連続線上に発生していると考 えられる。

ところで, 雲バンド a ・ f の発生率は, Table 2 に示 すように, NW 型・NNW 型で低い。特に NNW 型で は，5例中 1 例(1981年 2 月 2 日)で発生しているに過ぎ ない。そこで，2月 2 日の地上気圧分布図(Fig. 8 (a))を
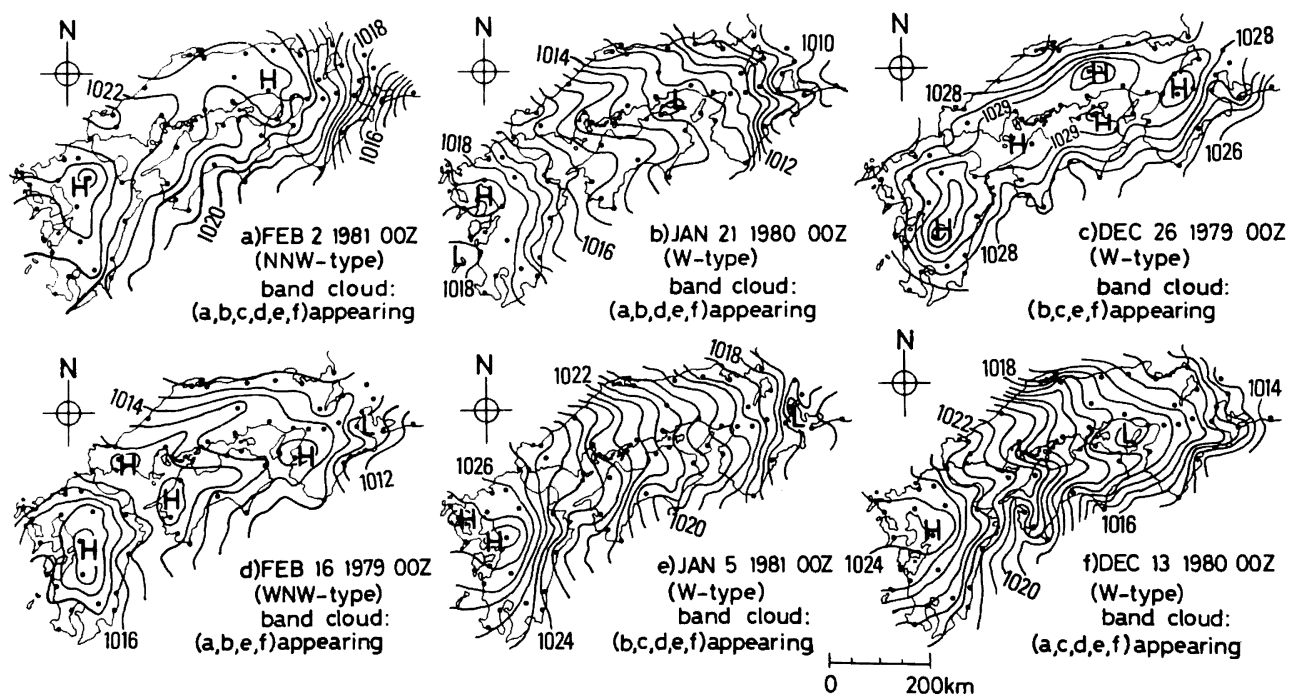

Fig. 8 Local weather map at $00 \mathrm{Z}$

(a) : on February 2 in 1981, (b) : on January 21 in 1980, (c) : on December 26 in 1979, (d): on February 16 in 1979, (e): on January 5 in 1981, (f) : on December 13 in 1980 , unit : $\mathrm{mb}$. 
$\mathrm{NNW}$ 型の平均地上気圧分布図 (Fig. 6 (b)) と比較すると，2月 2 日の方が，尾第・油津の低圧部が顕著 に現われることがわかる。特に NNW 型の場合は, 高層風向の北成分が強く, 一般場の等圧線の走向は, ほぼ南北ないし北北東一一南南西である。紀伊・九州両山地の走向も南北成分が大きく，一般場の等圧線 の走向と並行的である。そのため, 低圧部が発生しても, 一般にはその低圧部は雲バンドが発生するだけ の強さを持たない。したがって, 高層風向の北成分が大きい時は, 雲バンド $\mathrm{a} \cdot \mathrm{f}$ の発生率は低くなると 考えられる。

雲バンド $\mathrm{c} ・ \mathrm{~d}$ の発生率は, 高層風向の西成分が大きい時は, 低くなる傾向にある。Fig. 8 (b)は1980年 1 月21日の局地天気図で, この日は雲バンド c が発生していない。この日は, 高圧部が紀伊半島南部に向 かって張り出し, 室戸岬と潮岬の気圧差は $0.3 \mathrm{mb}$ である。そのため, 室戸岬の東には低圧部が存在しない。 Fig. 8 (c)は 1979年12月26日の局地天気図である。この日は雲バンド d が発生していない。この日は, 室戸 岬の西に突起状の低圧部が現われ, ここから 雲バンドが発生しているが, 高層風の西成分が大きく, 低圧 部よりも東側で積雲系の雲が発生していると考えられる。また，この日は，尾䧼付近の等圧線の 走向が

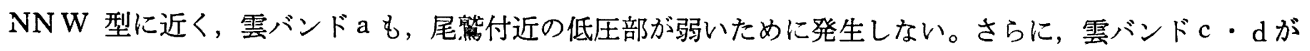
双方とも発生していない日（1979年 2 月16日）の局地天気図を Fig. 8 (d)に示す。この日は室戸岬と潮岬の 気圧差がなく，雲バンド $\mathrm{c}$ の発生する位置で低圧部が解析されていない。また，九州西部と四国西部の 局地高気圧が明瞭で, 九州山地の風下から豊後水道にかけての低圧部がはっきりしているのに対し, 高知 付近の低圧部は不明膫である。雲バンド $\mathrm{c} \cdot \mathrm{d}$ の発生しない場合の特徴は, 上記のように, 低圧部が弱い か, あるいは突起状の形をしていることである。四国山地はほぼ東西の走向を持つため, 高層風が西寄り の時は，QUENEY（1948）の示したような，風上の高圧部・風下の低圧部が，十分には現われない時があ ると考えられる。

2. 雲バンド $\mathrm{b}$ は, 高層風が西寄りの時は, 関門海峡から瀬戸内海を吹き抜けた風が 吹き出す位置に発 生している。W型の場合, 高松付近に低圧部が現われるが, これは, 西寄りの高層風に対して, 高松付近 が，中国・四国両山地の風下に 相当するためと考えられる。しかし, W型・WNW 型では, 雲バンド bの 発生率は低い。これを，1981年 1 月 5 日と1980年12月13日の地上気圧分布図 (Fig. 8(e), (f)) を比較するこ とにより考察する。前者が雲バンド b 発生する場合, 後者が 発生しない場合である。1月 5 日の地上 気圧分布図では，高松付近の低圧部ははっきりせず，四国山地から紀伊山地にかけての等圧線の張り出し 方は弱い。12月13日の地上気圧分布図では，淡路島付近に低気圧が認められ，等圧線が四国山地から紀伊 山地に強く張り出している。すでに, TSUCHIYA and FuJiTA (1967), TsuchiYA (1974), KUROSAKA（1983）などで明らかにされているように，雲バンドを形成する主体は，対流性の積雲系の雲であ る。したがって，四国山地から紀伊山地に張り出す高圧部が，積雲を形成するような対流を打ち消すだけ の強さを持つ時は, 雲バンド b は発生しないと考えられる。Fig. 8 (b)の例でも, 高圧部の張り出し方が弱 いので, 雲バンド b は発生する。Fig. 8 (d)の場合は, 高圧部の中に小さな低圧部が形成されており, この 低圧部から雲バンド $\mathrm{b} か ゙$ 発生している。

$\mathrm{NW}$ 型・NNW 型の時は, 中国山地の風下に低圧部が発生し, ここから風下側に延びる風の 不連続線 上に雲バンド $\mathrm{b}$ が発生する。すなわち, 雲バンド $\mathrm{a} \cdot \mathrm{c} \cdot \mathrm{d} \cdot \mathrm{f}$ の発生と同様に, 山地の風下に出現する 低圧部に, 雲バンドの発生位置を 対応させることができる。中国山地はほぼ東西の走向を持つので, 北成 分の大きい高層風に対しては，QUENEY（1948）の示したような，風下の低圧部の発生が起こりやすい状 況下にある。したがって, NW 型・NNW 型の時は, 雲バンド bの発生率が高くなると説明される。

3. 雲バンド e の発生は，関門海峡からの風の吹き出しで，基本的に説明される。しかし，W型の場合 は，この吹き出しの風と，九州山地の風上側からの風が，大分付近で収束し，ここに低圧部が出現する。 宮本（1981）が示した寒冷前線通過直後の強い吹き出し時の 局地天気図（Fig.7）にも，大分付近に小低 気圧が解析されている。雲バンド $\mathrm{e}$ はこの風の不連続線の上に発生し, 東西成分が比較的大きい。したが 
って, 高層風の西成分が大きい時は, 地上気象要素分布の特徴は, 今まで述べたような他の雲バンドの発 生の場合に類似している。

いっぽう，NW 型・NNW 型では，吹き出しの西側で温度勾配が大きく，豊後水道付近に比べて，九州 内陸部の気温は著しく低い。九州内陸部には高気圧が認められ，豊後水道は相対的に低圧部になってい る。それゆえ, 豊後水道には, この高気圧から冷気流が供給されると考えられる。したがって, 高層風の 北成分が大きい時は, 地上気象要素分布の特徵として, 関門海陕からの風の吹き出しと, 九州山地の風上 側に発生する高気圧から供給される冷気流の，2つが指摘される。ATLAS et al. (1983) は, アメリカ合 衆国 ニュージャージー州沖の雲バンドの発生に関して, 雲バンドの西側で温度勾配が大きく, 雲バンドの 位置に相当する低圧部に，冷気流が供給されることを指摘しているが，これも同様の現象であろう。

\section{v. まとめ}

本研究では, 冬季西南日本太平洋側に発生する雲バンドと, 地上気象要素分布の特徵との関連について 検討した。その結果, 以下の点が明らかになった。

1. 紀伊・四国・九州の各山地の風下に発生する雲バンドは, すべてこれらの山地の風下の低圧部から 発生している。その発生率は高層風向によって異なる。これは, これらの山地の走向と, 高層風向との関 連によって説明される。

2. 紀伊水道から発生する雲バンドは, 高層風向が北北西寄りの時は, 中国山地の風下の低圧部から伸 びる風の不連続線上に発生する。西寄りの時は, 関門海峡から瀬戸内海を通ってきた風の吹き出しの上に 発生する。しかし, 後者の場合, 高圧部が四国山地から 紀伊山地一強く張り出す時は, 雲バンドは発生し ない。

3. 豊後水道の雲バンドの発生には, 基本的に, 関門海峡からの 風の吹き出しが, 重要な役割を 果た す。高層風向が西寄りの時は, 九州山地の風上側に発生する局地高気圧からの風と, この吹き出しによる 風が収束し，風の不連続線が形成される。この不連続線上に雲バンドが発生する。高層風向が北北西寄り の時は, この吹き出しの西側に, 九州山地の風上側に発生する高気圧からの椧気流が供給され, その上に 雲バンドが発生する。

本研究では, 海水温ならびに海上観測点のデータは使用しなかったが, 特に海水温のデータの利用は, 物理的な雲バンドの発生機構の解明に手がかりを与え得る。また, たとえば, 寒気の吹き出し時の雲発生 に関係した混合層の発達を説明する STAGE and BUSINGER（1981a，b）のようなモデルを導入すれば, より定量的な考察が可能となろう。

また, もしも高層風向が西から北北西へ漸移する過程で, 雲バンドの発生が継続して見られるのであれ ば，地上気象要素分布の変化と，雲バンドの発生の変化の双方を，時間を追って解析することができよ う。雲バンドの発生から 消滅に至る一連の過程を, 地上気象要素分布の 推移と関連つけて 検討すること も，今後の興味ある課題である。

\section{謝 辞}

本研究を進めるにあたり，常日頃よりご指導いただいた鈴木秀夫・阪口豊両先生をはじめとする東京 大学理学部地理学教室の諸先生方に梁く感謝いたします。大学院生諸氏, 気候コロキウム諸兄からは, 有 益なご意見をいただきました。資料等の閱覧の際には，気象衛生センター解析課の岡田健吉氏をはしめと する方々,ならびに気象庁統計課の方々に便宜を計っていただきました。以上の方々に厚く御礼申し上げ ます。

\section{引用文献}

Atlas, D., Chou, S. -H. and Byerly, W. P. (1983): The Influence of Coastal Shape on 
Winter Mesoscale Air-sea Interaction. Mon. Wea. Rev., 111, 245-252.

CHOU, S. H. and AtLAS, D. (1982): Satellite Estimates of Ocean-air Heat Fluxes during Cold Air Outbreaks. Mon. Wea. Rev., 110, 1434-1450.

桎間道夫 (1980)：冬の季節風下での太平洋沿岸に㧍ける筋状雲の分布。地理評，53，345-347.

気象衛生センター編 (1983)：「ひまわり画像の見方」. 日本気象協会, $271 \mathrm{p}$.

黒坂裕之 (1981) : 気象衛生写真より見た冬季の日本周辺の雲分布の特徴. 東北地理，33，197-203.

(1982) : 冬季日本列島太平洋岸沖に出現するクラウド・ラインについて. 地理評, 55, 779-788. KUROSAKA, H. (1983) : Synoptic Climatological Study on the Conditions for Formation of Notes, 32, 1-66. 宮本正明（1981）：九州，中・四国山脈が西日本上の等圧線に及ぼす歪作用. 日本気象学会秋季大会配
布資料.

仁科淳司 (1984)：冬季季節風下における中部日本周边の雲分布に与える地形効果. 地理評， 57, 329348. 岡林俊雄 (1972) : 気象衛星からみた雪雲と降雪についての研究への利用. 気象研究ノート，113,
73-106.

QUeNEY, P. (1948): The Problem of Air Flow over Mountains: A Summary of Theoretical Studies. Bull. Amer. Met. Soc., 29, 16-26.

StAGE, S. A., Businger, J. A. (1981a): A Model for Entrainment into a Cloud-topped Marine Boundary Layer. Part I : Model Description and Application to a Cold-air Outbreak Episode. Jour. Atmos. Sci., 38, 2213-2229.

Part II : Discussion : A Model for Entrainment into a Cloud-topped Marine Boundary Layer. Sci., 38, 2230-2242.

TsUCHIYA, K. (1974): Cloud Features Associated with Mesoscale Phenomena during Cold Season as Revealed by Meteorological Satellite Pictures. Geophys. Mag., 37, 49-94.

mation over T. (1967): A Satellite Meteorological Study of Evaporation and Cloud ForSoc. Japan, 45, 232-250.

Yoshino, M. M. and KAI, K. (1974) : Pressure Pattern Calender of East Asia 1941-70, and Its Climatological Summary. Climatological Notes, 16, 1-71. 